\title{
PEMBUKTIAN TERHADAP PERBUATAN DEBITUR YANG MERUGIKAN KREDITUR DALAM TUNTUTAN ACTIO PAULIANA
}

Kajian Putusan Nomor 07/PDT.SUS-ACTIO PAULIANA/2015/PN.NIAGA.MDN

\section{PROOF OF THE ACTIONS OF THE DEBTOR THAT ADVERSE THE CREDITOR IN THE LAWSUIT OF ACTIO PAULIANA}

\author{
An Analysis of Decision Number 07/PDT.SUS-ACTIO PAULIANA/2015/PN.NIAGA.MDN
}

\author{
Elisabeth Nurhaini Butarbutar \\ Fakultas Hukum Unika Santo Thomas Sumatera Utara \\ Jl. Setia Budi No. 479 F Tanjung Sari Medan 20132 \\ Email: elisa_nurhaini@yahoo.com
}

Naskah diterima: 22 Mei 2018; revisi: 2 Mei 2019; disetujui 19 Agustus 2019

http://dx.doi.org/10.29123/jy.v12i2.322

\section{ABSTRAK}

Actio pauliana merupakan upaya hukum kreditur untuk membatalkan perbuatan debitur yang merugikan kreditur melalui pengadilan asal dapat dibuktikan bahwa ketika perbuatan dilakukan, debitur ataupun orang dengan siapa debitur berbuat, mengetahui bahwa perbuatan itu dapat merugikan kreditur. Pembuktian terhadap unsur mengetahui tersebut tidaklah sederhana karena berkaitan dengan perilaku. Dalam Putusan Nomor 07/PDT. SUS-ACTIO PAULIANA/2015/PN.NIAGA.MDN, timbul masalah bagaimana hakim menilai pembuktian gugatan actio pauliana, dan pertimbangan hukum apa yang diberikan oleh hakim untuk menyatakan bahwa perbuatan para tergugat merupakan perbuatan melawan hukum. Penelitian ini menggunakan metode penelitian yang bersifat yuridis normatif. Penilaian hakim terhadap pembuktian unsur mengetahui didasarkan pada pengakuan tergugat bahwa terjadi penjualan aset dan transfer dana dari tergugat I kepada tergugat VII untuk tujuan agar tergugat I tetap dapat beroperasi dan memenuhi kewajiban hutangnya kepada para
\end{abstract}

krediturnya. Pertimbangan hakim menyatakan bahwa perbuatan para tergugat sebagai perbuatan melawan hukum didasarkan pada perbuatan jual beli tersebut dilakukan oleh orang yang sama sehingga bertentangan dengan Pasal 1457 KUHPerdata, tidak dilakukan orang yang berwenang berdasarkan Peraturan Batas Kewenangan Keuangan Perusahaan (Financial Limited Authority) yang berlaku di grup perusahaan. Serta pembayaran oleh tergugat I kepada tergugat VII dengan cara set off tidak sesuai dengan Pasal 1425, 1426, 1427 KUHPerdata.

Kata kunci: actio pauliana, pembuktian, unsur mengetahui, kerugian, perbuatan melawan hukum.

\section{ABSTRACT}

Actio pauliana is a creditor's legal effort to cancel the debtor's actions that adverse the creditor through the court of origin, it can be proven that when the act is committed, the debtor or the person with whom the debtor is acting, knows that the act can adverse the creditor. Proof of the element of knowing is not that simple 
because it related to behavior. In Decision Number 07/PDT.SUS-ACTIO

PAULIANA/2015/PN.NIAGA.

$M D N$, a problem arises on how the judge assessed the evidence of the actio pauliana lawsuit, and what legal considerations that given by the judge in declaring that the actions of the defendants were unlawful. This research is using normative juridical research methods. The judges' assessment of the evidence element based on the defendant's confession that there were an asset selling and fund transfers from the first defendant to the seventh defendant and the purpose is to make the first defendant keep continue operating and fulfill its debt

\section{PENDAHULUAN}

\section{A. Latar Belakang}

Actio pauliana merupakan upaya hukum yang diberikan oleh undang-undang kepada kreditur untuk membatalkan perbuatan debitur yang merugikan kreditur. Tujuan dari actio pauliana ini adalah untuk menghindari kerugian dari para krediturnya, dengan cara memohon kepada pengadilan agar membatalkan tindakan hukum debitur yang dianggap dapat merugikan krediturnya. Actio pauliana terkandung dalam Pasal 1341 KUHPerdata, yang menentukan bahwa setiap kreditur dapat mengajukan pembatalan segala perbuatan yang tidak diwajibkan yang dilakukan oleh debitur dengan nama apapun, juga yang merugikan kreditur, asal dapat dibuktikan bahwa ketika perbuatan dilakukan, baik debitur ataupun orang dengan atau untuk siapa debitur berbuat, mengetahui bahwa perbuatan itu membawa akibat yang merugikan kreditur.

Actio pauliana kemudian diadopsi oleh Undang-Undang Nomor 37 Tahun 2004 tentang Kepailitan dan Penundaan Kewajiban Pembayaran Utang, yang dalam Pasal 41 ayat (1) menentukan bahwa untuk kepentingan harta obligations to its creditors. The judge's consideration stated that the actions of the defendants as unlawful acts were based on the act of buying and selling that carried out by the same person so that was contrary to Article 1457 of the Civil Code, no authorized person was carried out under the Financial Limited Authority Rules that apply in the group company. Moreover, the payment by the first defendant to seventh defendant by setting off was not in accordance with Article 1425, 1426, 1427 of the Civil Code.

Keywords: actio pauliana, proof, knowing elements, adverse, unlawful acts.

pailit, kepada pengadilan dapat dimintakan pembatalan segala perbuatan hukum debitur yang telah dinyatakan pailit yang merugikan kepentingan kreditur, yang dilakukan sebelum putusan pernyataan pailit diucapkan.

Pasal 41 ayat (2) Undang-Undang Nomor 37 Tahun 2004, menetapkan pembatalan sebagaimana dimaksud pada ayat (1) hanya dapat dilakukan apabila dapat dibuktikan bahwa pada saat perbuatan hukum dilakukan, debitur dan pihak dengan siapa perbuatan hukum tersebut dilakukan mengetahui atau sepatutnya mengetahui bahwa perbuatan hukum tersebut akan mengakibatkan kerugian bagi kreditur. Selanjutnya menurut Pasal 42 Undang-Undang Nomor 37 Tahun 2004, apabila perbuatan hukum yang merugikan kreditur tersebut dilakukan dalam jangka waktu satu tahun sebelum putusan pernyataan pailit diucapkan, sedangkan perbuatan tersebut tidak wajib dilakukan debitur, kecuali dapat dibuktikan sebaliknya, maka debitur dan pihak dengan siapa perbuatan tersebut dilakukan dianggap mengetahui atau sepatutnya mengetahui bahwa perbuatan tersebut akan mengakibatkan kerugian bagi kreditur sebagaimana dimaksud dalam Pasal 41 ayat (2). 
Pengecualian yang dimaksud didasarkan pada Pasal 41 ayat (3) Undang-Undang Nomor 37 Tahun 2004, di mana debitur pailit dapat mengambil tindakan hukum sepanjang tindakan tersebut bukan untuk kepentingan pribadi, melainkan untuk menyehatkan perusahaan. Berdasarkan ketentuan tersebut, maka diketahui bahwa persoalan pokok dalam gugatan actio pauliana adalah dapat dibuktikan bahwa pada saat perbuatan hukum dilakukan, debitur dan pihak dengan siapa perbuatan hukum tersebut dilakukan mengetahui atau sepatutnya mengetahui bahwa perbuatan hukum tersebut akan mengakibatkan kerugian bagi kreditur.

Pembuktian bertujuan untuk memberi keyakinan kepada hakim tentang peristiwa atau dalil-dalil yang dikemukakan oleh pihak-pihak, sehingga ditemukan peristiwa yang benar-benar terjadi(Butarbutar, 2016: 168). Problematik dalam hukum pembuktian adalah beban pembuktian dan menilai pembuktian. Ajaran beban pembuktian, mempersoalkan siapa yang harus membuktikan. Sesuai dengan asas actori incumbit probatio yang terkandung dalam Pasal 163 HIR/Pasal 283 Rbg dan Pasal 1865 KUHPerdata, maka yang wajib membuktikan adalah siapa yang mengemukakan suatu peristiwa atau hak, dan apabila peristiwa atau hak itu dibantah, maka pihak tersebut wajib membuktikan bantahannya. Dalam pembuktian, yang harus dibuktikan adalah peristiwa yang disengketakan, hal ini berkaitan dengan asas ius curia novit, bahwa hakim dianggap tahu semua hukum, sehingga yang perlu diketahui oleh hakim melalui persidangan adalah peristiwa/faktanya untuk nantinya diterapkan hukumnya.

Dihubungkan dengan gugatan actio pauliana dalam Pasal 1341 KUHPerdata jo. Pasal 41 ayat (2) Undang-Undang Nomor 37 Tahun 2004, maka yang harus dibuktikan adalah peristiwa perbuatan hukum yang dilakukan oleh debitur dan pihak dengan siapa perbuatan hukum tersebut dilakukan, mengetahui atau sepatutnya mengetahui akan mengakibatkan kerugian bagi kreditur. Selain dapat dibuktikan perbuatan hukum yang merugikan kreditur, gugatan actio pauliana hanya dapat diajukan apabila:

1. Debitur sudah dinyatakan pailit dengan putusan hakim;

2. Perbuatan tersebut dilakukan dalam jangka waktu satu tahun sebelum putusan pailit diucapkan;

3. Perbuatan tersebut tidak wajib dilakukan debitur berdasarkan perjanjian maupun undang-undang.

Berdasarkan Putusan Nomor 07/PDT. SUS-PKPU/2014/PN.NIAGA.MDN, bahwa PT HEI dinyatakan pailit, sehingga lahir hubungan hukum antara penggugat dengan tergugat I sebagai kurator dengan debitur. Dalam gugatannya, kurator mendalilkan bahwa penjualan aset dengan cara menjual aset (boedel pailit) kepada tergugat II, dan mentransfer dana hasil penjualan kepada tergugat VII dalam kurun waktu satu tahun sebelum pernyataan pailit, dinilai dapat menimbulkan kerugian bagi para krediturnya, karena tindakan tersebut dianggap hanya untuk menghindar dari kewajiban membayar dan melunasi seluruh utang-utangnya. Berdasarkan Putusan Homologasi Perdamaian antara tergugat I dengan para krediturnya, tanggal 8 Juli 2014, bahwa tergugat II dan tergugat VII tidak terverifikasi sebagai kreditur yang berhak menerima pembayaran dari tergugat I.

Putusan Nomor 07/PDT.SUS-ACTIO PAULIANA/2015/PN.NIAGA.MDN, hakim memutuskan untuk menerima dan mengabulkan 
gugatan actio pauliana untuk seluruhnya dan menyatakan perbuatan hukum tergugat I, tergugat II, tergugat III, tergugat IV, tergugat $\mathrm{V}$, tergugat VI, tergugat VII, yang dilakukan dalam jual beli aset tergugat I tersebut melawan hukum karena merugikan para kreditur dan tidak sah menurut hukum.

Putusan tersebut didasarkan pada pertimbangan/penilaian bahwa penggugat dapat membuktikan peristiwa yang disengketakan, yaitu perbuatan tergugat I untuk mengalihkan dengan cara menjual aset kepada tergugat II dan dana hasil penjualan boedel pailit ditransfer kepada tergugat VII dengan cara set off. Menyebabkan tergugat I tidak mempunyai dana untuk melunasi kewajibannya pada para krediturnya, dan perbuatan itu dilakukan dalam kurun waktu satu tahun sebelum pernyataan pailit tergugat I diucapkan.

Berdasarkan ketentuan Pasal 1341 KUHPerdata jo. Pasal 41 ayat (2) UndangUndang Nomor 37 Tahun 2004, pembatalan dapat dilakukan apabila dapat dibuktikan bahwa pada saat perbuatan hukum dilakukan, debitur dan pihak dengan siapa perbuatan hukum tersebut dilakukan mengetahui atau sepatutnya mengetahui bahwa perbuatan hukum tersebut akan mengakibatkan kerugian bagi kreditur.

Pembuktian terhadap ketiga peristiwa di atas tidak sesederhana membuktikan bahwa ketika perbuatan dilakukan baik debitur ataupun orang dengan atau untuk siapa debitur berbuat, mengetahui bahwa perbuatan itu membawa akibat yang merugikan kreditur, karena peristiwa tersebut berkaitan dengan perilaku yang mengakibatkan kerugian pada kreditur. Oleh karena itu, timbul permasalahan yang akan dicari jawaban dalam penelitian ini adalah penilaian hakim tentang adanya unsur mengetahui atau sepatutnya mengetahui bahwa perbuatan hukum para tergugat akan mengakibatkan kerugian bagi kreditur sebagai dasar mengajukan pembatalan terhadap semua perbuataan tergugat, dan pertimbangan hukum yang diberikan oleh hakim untuk memutuskan bahwa perbuatan para tergugat merupakan perbuatan melawan hukum.

\section{B. Rumusan Masalah}

Sebagai permasalahan dalam penelitian ini dirumuskan sebagai berikut:

1. Bagaimana hakim menilai pembuktian adanya unsur mengetahui atau sepatutnya mengetahui bahwa peristiwa perbuatan hukum yang dilakukan oleh para tergugat akan mengakibatkan kerugian bagi kreditur sebagai dasar mengajukan gugatan actio pauliana dalam Putusan Nomor 07/ PDT.SUS-ACTIO PAULIANA/2015/ PN.NIAGA.MDN?

2. Pertimbangan hukum apa yang diberikan oleh hakim untuk menyatakan bahwa perbuatan para tergugat merupakan perbuatan melawan hukum?

\section{Tujuan dan Kegunaan}

Adapun yang menjadi tujuan dari penelitian ini adalah untuk mengetahui penilaian hakim terhadap pembuktian, bahwa perbuatan hukum yang dilakukan oleh para tergugat dianggap sudah diketahui atau sepatutnya diketahui para tergugat akan mengakibatkan kerugian bagi kreditur dalam gugatan actio pauliana dalam Putusan Nomor 07/PDT.SUS-ACTIO PAULIANA/2015/ PN.NIAGA.MDN, dan pertimbangan hukum yang diberikan oleh hakim untuk menyatakan 
bahwa perbuatan para tergugat merupakan perbuatan melawan hukum.

Kegunaan atau manfaat yang dapat diperoleh dari penelitian ini adalah untuk memberikan kontribusi serta sumbangan pemikiran bagi pengembangan ilmu hukum, khususnya hukum acara. Di samping itu secara praktis, dapat membantu pemerintah dalam menciptakan kepastian hukum bagi masyarakat dalam menganalisis putusan yang berkaitan dengan pembuktian atas adanya perbuatan hukum yang merugikan kreditur.

\section{Tinjauan Pustaka \\ 1. Asas Actio Pauliana}

Menurut Pasal 41 ayat (1) Undang-Undang Nomor 37 Tahun 2004, untuk kepentingan harta pailit, kepada pengadilan dapat dimintakan pembatalan segala perbuatan hukum debitur yang telah dinyatakan pailit yang merugikan kepentingan kreditor, yang dilakukan sebelum putusan pernyataan pailit diucapkan. Actio pauliana ini terkandung dalam Pasal 1341 KUHPerdata, yang kemudian diadopsi oleh Pasal 41 ayat (1) Undang-Undang Nomor 37 Tahun 2004, untuk melindungi harta pailit dari tindakan debitur yang nakal. Pasal 1341 KUHPerdata memberikan hak kepada setiap kreditur untuk mengajukan pembatalan segala perbuatan yang tidak diwajibkan yang dilakukan oleh debitur dengan nama apapun, juga yang merugikan kreditur, asal dapat dibuktikan bahwa ketika perbuatan dilakukan baik debitur ataupun orang dengan atau untuk siapa debitur berbuat, mengetahui bahwa perbuatan itu membawa akibat yang merugikan kreditur.

Hak kreditur dalam asas actio pauliana ini berkaitan dengan akibat putusan pailit, yaitu perusahaan harus menghentikan segala aktivitasnya, dan dengan demikian dilarang mengadakan transaksi dengan pihak lain kecuali untuk likuidasi (Sidabalok, 2012: 226). Ketentuan kepailitan ini merupakan realisasi dari Pasal 1131 KUHPerdata yang menentukan bahwa segala kebendaan/kekayaan milik debitur, baik yang bergerak maupun tidak bergerak, yang sudah ada maupun yang akan ada di kemudian hari, menjadi tanggungan atau jaminan untuk segala perikatan seseorang. Hal ini berarti seluruh kekayaan debitur ditetapkan menjadi jaminan atas seluruh hutang-hutangnya, yang mengakibatkan debitur tidak dapat berbuat bebas terhadap kekayaannya. Melalui actio pauliana ini, undang-undang membatasi debitur untuk bertindak atas kekayaan yang dimilikinya dengan memberikan hak kepada kreditur untuk meminta pembatalan terhadap tindakan debitur, jika tindakan debitur itu bermaksud merugikan kreditur.

Actio pauliana ini merupakan hak kreditur untuk membatalkan perbuatan hukum yang diadakan debiturnya dengan pihak ketiga. Artinya kreditur bukan merupakan pihak dalam perbuatan hukum tersebut, namun kreditur mempunyai kepentingan dengan tindakan debiturnya jika tindakan itu dapat merugikan kepentingannya. Untuk mengajukan pembatalan, kreditur harus dapat membuktikan bahwa ketika perbuatan dilakukan baik debitur ataupun orang dengan atau untuk siapa debitur berbuat, mengetahui bahwa perbuatan itu membawa akibat yang merugikan bagi kreditur.

Pada dasarnya hubungan hukum perdata terjadi karena adanya dua pihak mengikatkan diri yang melahirkan hak di satu pihak dan kewajiban di pihak lain. Hak untuk menuntut prestasi di satu pihak (kreditur) dan kewajiban untuk melakukan prestasi (debitur), lahir dari adanya 
suatu hubungan hukum dalam lapangan hukum harta kekayaan yang dikenal dengan perikataan. Tuntutan prestasi dalam perikatan dapat dilakukan, baik akibat kerugian yang diakibatkan adanya ingkar janji (wanprestasi), ataupun akibat timbulnya kerugian karena perbuatan melawan hukum (onrechtmatige daad). Oleh karena itu hubungan perdata dapat lahir karena disepakati bersama, ataupun karena undang-undang.

Sebagai pihak ketiga, kreditur hanya dapat melakukan pembatalan segala perbuatan yang tidak diwajibkan yang dilakukan oleh debiturnya, yang merugikan kreditur atas dasar perbuatan melawan hukum. Tuntutan pembatalan tersebut dapat diajukan berdasarkan Pasal 1341 KUHPerdata, yang kemudian diadopsi oleh Pasal 41 ayat(1) Undang-Undang Nomor37 Tahun2004, bahwa untuk kepentingan harta pailit, kepada pengadilan dapat dimintakan pembatalan segala perbuatan hukum debitur yang telah dinyatakan pailit yang merugikan kepentingan kreditur, yang dilakukan sebelum putusan pernyataan pailit diucapkan. Atas dasar merugikan kepentingan pihak ketiga yang sekaligus sebagai kreditur dari debitur untuk membatalkan perbuatan hukum debiturnya dengan pihak lain.

Pembatalan merupakan salah satu cara untuk menghapuskan perikatan menurut Pasal 1381 KUHPerdata, harus didahului dengan tindakan hukum untuk mengakhiri kekuatan mengikatnya perikatan. Tindakan hukum yang harus dilakukan adalah tuntutan atau permohonan pembatalan oleh pihak yang merasa mempunyai kepentingan untuk itu, baik karena adanya wanprestasi maupun karena perbuatan melawan hukum (Butarbutar, 2012: 152). Pembatalan oleh pihak ketiga berkaitan dengan asas pribadi yang terkandung dalam ketentuan Pasal 1315 jo. Pasal 1340 KUHPerdata, bahwa perjanjian hanya berlaku antara pihak-pihak yang membuatnya. Pembatalan yang dapat diajukan oleh kreditur terhadap perbuatan hukum yang dilakukan oleh debitur merupakan pembatalan relatif. Artinya yang dapat mengajukan pembatalan hanyalah kreditur saja, dan perjanjian yang diadakan tetap berlaku bagi pihak-pihak yang mengadakan perjanjian tersebut, namun tidak mempunyai akibat hukum bagi kreditur (Siahaan, 2017: 104).

\section{Perbuatan Melawan Hukum}

Perbuatan melawan hukum (onrechtmatige daad) ditemukan dalam Pasal 1365 KUHPerdata, yang menentukan tiap-tiap perbuatan yang melanggar hukum dan membawa kerugian kepada orang lain, mewajibkan orang yang menimbulkan kerugian itu karena kesalahannya untuk menggantikan kerugian tersebut. Berdasarkan ketentuan Pasal 1365 KUHPerdata tersebut, maka dalam satu gugatan perbuatan melawan hukum, penggugat harus mampu membuktikan adanya unsur perbuatan melawan hukum yang ditentukan dalam ketentuan Pasal 1365 tersebut, yaitu suatu perbuatan yaitu perbuatan melanggar hukum, adanya kesalahan, adanya kerugian, dan antara kerugian dan kesalahan mempunyai hubungan sebab akibat.

Pasal 1365 KUHPerdata tidak menyebutkan pengertian keempat unsur tersebut, namun jika dihubungkan dengan Pasal 1337 KUHPerdata yang mengatur tentang kausa yang tidak halal, maka unsur perbuatan melanggar hukum, dapat diartikan sebagai perbuatan melanggar undangundang, melanggar ketertiban umum, maupun perbuatan melanggar kesusilaan.

Dalam halnya perjanjian jual beli menurut Pasal 1457 KUHPerdata, maka jual beli harus dilakukan antara dua pihak yang berada dalam 
posisi yang berbeda, di mana pihak yang satu adalah pihak yang berhak (kreditur) atas suatu prestasi, dan pihak lainnya merupakan pihak yang wajib melaksanakan prestasi (debitur). Di samping kewajiban penjual untuk menyerahkan barang yang diperjualbelikan kepada pembeli, penjual wajib menanggung atau menjamin penguasaan barang yang dijual secara aman (Miru, 2017: 133). Apabila jual beli dilakukan oleh pihak yang sama, atau dilakukan oleh debitur yang merupakan badan hukum dengan atau terhadap badan hukum lain dalam satu grup, di mana debitur adalah anggotanya sebagaimana ditentukan dalam Pasal 42 huruf f UndangUndang Kepailitan, maka perbuatan jual beli tersebut melanggar Pasal 1457 KUHPerdata.

Secara teoritis, unsur kesalahan dalam hukum perdata mempunyai arti subjektif atau abstrak, dan kesalahan dalam arti objektif atau konkret(Djojodirdjo, 1979: 32). Kesalahan dalam arti subjektif atau abstrak yaitu menyangkut hal perbuatan itu dapat dipersalahkan kepadanya apabila pelaku dapat menginsafi akibat dari perbuatannya. Ini artinya perbuatan tersebut disadari oleh pelaku akan menyebabkan kerugian pada orang lain. Sedangkan kesalahan dalam arti objektif (konkret) diartikan sebagai perbuatan yang dapat dipertanggungjawabkan kepada pelaku apabila perbuatan itu tidak dilakukan dalam keadaan terpaksa (overmacht) atau tidak karena keadaan darurat (noodtoestand).

Menurut Satrio (1993: 239), perilaku dan kerugian menjadi unsur dapat dipersalahkan, dan oleh karenanya dapat dipertanggungjawabkan kepadanya. Jadi unsur mengetahui atau patut mengetahui dapat dibuktikan dengan membuktikan adanya kesalahan dan dapat dipertanggungjawabkan.

\section{Penilaian Pembuktian}

Hak pembatalan melalui actio pauliana, disertai dengan beban pembuktian (bewijslast) kepada kreditur, untuk membuktikan bahwa peristiwa pebuatan hukum yang tidak diwajibkan menimbulkan kerugian pada kreditur. Menurut Subekti (2007: 34) membuktikan berarti meyakinkan hakim tentang kebenaran dalildalil yang dikemukakan dalam suatu sengketa. Oleh karena itu, pembuktian hanya diberikan apabila timbul suatu perselisihan. Pembuktian peristiwa penting untuk membenarkan adanya suatu hak (Samosir, 2011: 213). Dalam proses beracara, hakim dilarang menjatuhkan putusan tanpa melalui proses pembuktian terlebih dahulu, karena melalui pembuktian inilah hakim mengetahui kepastian atau kebenaran peristiwa yang disengketakan oleh pihak-pihak.

Dalam pembuktian perdata, yang harus dibuktikan adalah peristiwa atau hak yang disengketakan. Berdasarkan asas actori incumbit probatia yang terkandung dalam Pasal 163 HIR/ Pasal 283 Rbg dan Pasal 1865 KUHPerdata, maka yang dibuktikan adalah fakta atau peristiwa, karena membuktikan sesuatu yang tidak ada atau sesuatu hal yang negatif pada umumnya tidak mungkin (negativa non sunt probanda). Tentang pembuktian negatif, Paton (1975: 483) berpendapat: "should not be forced on a person without very strong reason." Tugas hakim dalam pembuktian adalah membebani pihakpihak untuk membuktikan, atau memerintahkan para pihak untuk membuktikan dalil-dalil yang dikemukakannya, dan untuk menilai pembuktian yang diajukan oleh pihak-pihak tersebut.

Pasal 8 ayat (4) Undang-Undang Nomor 37 Tahun 2004 menetapkan bahwa permohonan pernyataan pailit harus dikabulkan apabila 
terdapat fakta atau keadaan yang terbukti secara sederhana. Penjelasan Pasal 4 tersebut menjelaskan bahwa fakta atau keadaan yang terbukti secara sederhana, adalah adanya fakta dua atau lebih kreditur, dan fakta utang yang telah jatuh waktu dan tidak dibayar. Perbedaan besarnya jumlah utang yang didalilkan oleh pemohon pailit dan termohon pailit, tidak menghalangi dijatuhkannya putusan pernyataan pailit. Penerapan pembuktian sederhana ini menjadi kekhususan dari proses beracara perkara kepailitan dan penundaan kewajiban pembayaran utang.

Berbeda dengan pembuktian dalam perkara perdata pada umumnya yang diatur dalam HIR/ Rbg, pembuktian sederhana ini tidak memerlukan pembuktian dari pihak lawan. Sedangkan pengertian pembuktian dalam hukum acara, pembuktian selalu dapat dilumpuhkan oleh bukti lawan walaupun sudah diajukan dengan bukti lengkap, kecuali bukti yang bersifat menentukan atau memutuskan, seperti alat bukti sumpah dan alat bukti pengakuan.

Pada dasarnya, sepanjang undang-undang tidak mengatur sebaliknya, hakim bebas untuk menilai pembuktian. Apabila alat bukti dinilai oleh hakim cukup memberi kepastian tentang peristiwa yang disengketakan untuk menjatuhkan putusan, maka peristiwa itu harus dianggap sudah pasti atau benar, dan alat bukti itu dinilai lengkap atau sempurna, kecuali kalau ada pembuktian lawan yang melumpuhkan alat bukti tersebut. Hakim dapat menjatuhkan putusan secara apriori terhadap permohonan pailit dan penundaan pembayaran utang, tanpa membuktikan terlebih dahulu kebenaran dan fakta yang diajukan debitur. Dalam praktik, adanya pembuktian sederhana ini ternyata berpotensi untuk disalahgunakan oleh debitur, baik perorangan maupun badan hukum yang "nakal," untuk memohonkan ke pengadilan niaga agar dirinya dinyatakan pailit. Padahal kenyataan yang sebenarnya adalah debitur merekayasa dirinya sendiri sedemikian rupa, dengan meminjam dalam jumlah yang cukup banyak dari lebih seorang kreditur, dan kemudian seketika berhenti membayar, dengan demikian memenuhi syarat untuk mengajukan permohonan pailit (Butarbutar, 2001: 130).

Sekalipun peristiwa yang disengketakan telah diajukan pembuktian, namun pembuktian itu harus dinilai oleh hakim. Apabila alat bukti yang diajukan dinilai hakim cukup memberikan kepastian tentang peristiwa yang disengketakan, maka peristiwa itu dianggap sudah pasti, dan alat bukti tersebut dinilai sudah lengkap dan sempurna, kecuali ada pembuktian lawan yang melumpuhkan alat bukti tersebut. Pada dasarnya, sepanjang undang-undang tidak mengatur sebaliknya, hakim bebas untuk menilai pembuktian. Menilai pembuktian menjadi dasar bagi hakim untuk menjatuhkan putusan. Alasan atau pertimbangan menjadi dasar pertanggungjawaban hakim pada putusannya (Mertokusumo, 2013: 15).

\section{METODE}

Secara umum tujuan penelitian adalah untuk memperoleh jawaban atas permasalahan yang diajukan (Butarbutar, 2018: 122). Berkaitan dengan permasalahan yang diajukan dalam penelitian ini, maka tujuan penelitian ini adalah untuk menganalisis proses pembuktian adanya unsur mengetahui, atau sepatutnya mengetahui bahwa perbuatan debitur akan mengakibatkan kerugian kreditur, dan menganalisis pertimbangan hukum hakim untuk menetapkan tindakan debitur tersebut sebagai perbuatan melawan hukum melalui analisis terhadap bahan hukum, 
yaitu Putusan Nomor 07/PDT.SUS-ACTIO PAULIANA/2015/PN.NIAGA.MDN.

Penelitian ini menggunakan metode penelitian yang bersifat yuridis normatif. Penelitian yuridis normatif adalah penelitian yang mengkaji berbagai peraturan perundangundangan yang berlaku atau diterapkan terhadap suatu permasalahan hukum tertentu. Penelitian hukum normatif seringkali disebut juga dengan penelitian hukum doktrinal, yaitu penelitian yang objek kajiannya adalah dokumen peraturan perundang-undangan dan bahan pustaka (Soejono \& Abdurahman, 2003: 56).

Data sekunder yang terdapat dalam bahan hukum yang terdiri dari bahan hukum primer, yaitu bahan hukum yang mengikat atau bahan hukum autoritatif, yang artinya mempunyai otoritas (Marzuki, 2014: 181). Bahan hukum sekunder yaitu bahan hukum yang memberikan penjelasan pada bahan hukum primer, yaitu berupa literatur dan jurnal atau karya ilmiah lainnya yang berkaitan dengan pembuktian dalam gugatan actio pauliana, dan bahan hukum tersier yang memberikan penjelasan pada bahan hukum primer maupun bahan hukum sekunder yang terdapat dalam Kamus Hukum, Kamus Besar Bahasa Indonesia, serta ensiklopedia.

Teknik pengumpulan data dilakukan dengan studi dokumen. Data yang diperoleh kemudian diolah dan dianalisis secara preskriptif dan deskriptif. Dalam penelitian hukum normatif, pengolahan data diartikan sebagai kegiatan sistematisasi terhadap bahan-bahan hukum dengan membuat klasifikasi data untuk memudahkan analisis dan konstruksi (Soekanto, 2012: 251). Oleh karena sifat hukum itu sendiri adalah preskriptif atau mengharuskan, maka analisis dilakukan secara preskriptif.
Dimaksudkan untuk memberikan argumentasi atas hasil penelitian yang telah dilakukan, dengan tujuan memberikan mengenai benar atau salah atau apa yang seyogianya menurut hukum atas fakta atau peristiwa hukum dari hasil penelitian yang dilakukan (Fajar \& Achmad, 2015: 183). Analisis deskriptif merupakan analisis dengan cara menggambarkan atau memaparkan subjek dan objek penelitian yang telah dilakukan.

\section{HASIL DAN PEMBAHASAN}

\section{A. Penilaian Pembuktian Unsur "Mengetahui" atau "Patut Mengetahui"}

Pasal 41 Undang-Undang Nomor 37 Tahun 2004 tidak menjelaskan apa yang dimaksud dengan merugikan kepentingan kreditur, selain hanya menyebutkan dalam Pasal 41 ayat (2) bahwa pembatalan sebagaimana dimaksud pada ayat (1) dapat dilakukan apabila dapat dibuktikan bahwa pada saat perbuatan hukum dilakukan, debitur dan pihak dengan siapa perbuatan hukum itu dilakukan mengetahui atau sepatutnya mengetahui bahwa perbuatan hukum tersebut akan mengakibatkan kerugian bagi kreditur.

\section{Pasal 42 Undang-Undang Nomor 37}

Tahun 2004 menyatakan perbuatan hukum yang merugikan kreditur dilakukan dalam jangka waktu satu tahun sebelum putusan pernyataan pailit diucapkan, sedangkan perbuatan tersebut tidak wajib dilakukan debitur, kecuali dapat dibuktikan sebaliknya, debitur dan pihak dengan siapa perbuatan tersebut dilakukan dianggap mengetahui atau sepatutnya mengetahui bahwa perbuatan tersebut akan mengakibatkan kerugian bagi kreditur. Ini artinya, terdapat unsur "mengetahui atau sepatutnya mengetahui" akibat perbuatan debitur menjadi persoalan pokok yang harus dibuktikan untuk menentukan adanya kerugian. 
Untuk membuktikan unsur mengetahui atau patut mengetahui dalam hukum tidak sesederhana membuktikan peristiwa/fakta yang didalilkan oleh pihak-pihak. Sesuai asas actori incumbit probatia, maka yang dibuktikan adalah fakta atau peristiwa. Sesuatu bukan fakta sulit dibuktikan, sebagaimana dikenal dengan asas negativa non sunt probanda. Unsur mengetahui atau patut mengetahui berkaitan dengan perilaku dan akibat perilaku yaitu kerugian. Jadi unsur mengetahui atau patut mengetahui dapat dibuktikan dengan membuktikan adanya kesalahan dan dapat dipertanggungjawabkan.

Unsur kesalahan dalam hukum perdata, mempunyai arti subjektif atau abstrak, dan kesalahan dalam arti objektif atau konkret. Kesalahan dalam arti subjektif atau abstrak, yaitu menyangkut hal perbuatan itu dapat dipersalahkan kepadanya apabila pelaku dapat menginsafi akibat dari perbuatannya, dalam arti perbuatan tersebut disadari oleh pelaku akan menyebabkan kerugian pada orang lain. Sedangkan kesalahan dalam arti objektif (konkret), diartikan sebagai perbuatan yang dapat dipertanggungjawabkan kepada pelaku dalam arti perbuatan itu tidak dilakukan dalam keadaan terpaksa (overmacht), atau tidak karena keadaan darurat (noodtoestand).

Unsur kesalahan dalam menentukan adanya perbuatan melawan hukum merupakan komponen utama untuk menentukan apakah pelaku dapat dipertanggungjawabkan. Dalam perkara pidana unsur kesalahan ini berkaitan dengan unsur sengaja (dolus) dan culva, yang merupakan salah satu unsur untuk menentukan adanya tindak pidana. Untuk dapat membuktikan adanya unsur mengetahui atau patut mengetahui sebagai unsur mengajukan pembatalan menurut Pasal 41 ayat (2) Undang-Undang Nomor 37 Tahun 2004, maka terlebih dahulu dibuktikan hal-hal sebagai berikut:
1. Ada perbuatan yang membawa kerugian pada kreditur;

2. Perbuatan itu dilakukan sebelum putusan pailit;

3. Perbuatan itu tidak diwajibkan oleh perjanjian atau undang-undang.

Putusan Nomor 07/PDT.SUS-ACTIO PAULIANA/2015/PN.NIAGA.MDN, hakim menilai bahwa peristiwa mengalihkan aset pailit kepada tergugat II dan mentransfer dana hasil penjualannya kepada tergugat VII, dapat dibuktikan oleh penggugat. Sehingga tindakan para tergugat dan turut tergugat harus dibatalkan, karena dapat mengakibatkan kerugian kepada krediturnya.

Dasar penilaian hakim untuk membatalkan perbuatan hukum dianggap merugikan kreditur dalam Putusan Nomor 07/PDT.SUS-ACTIO PAULIANA/2015/PN.NIAGA.MDN, tentu harus didasarkan pada penilaian telah terbuktinya peristiwa/fakta yang disengketakan. Setiap unsur-unsur yang menjadi syarat mengajukan tuntutan actio pauliana merupakan fakta sebagai kebenaran terjadinya peristiwa itu, yaitu:

1) Ada Perbuatan yang Membawa Kerugian pada kreditur

Berdasarkan Putusan Nomor 07/PDT.SUSPKPU/2014/PN.NIAGA.MDN, tanggal 9 Juli 2015 PT HEIdinyatakan pailit, sehingga hubungan hukum antara penggugat dengan tergugat I adalah hubungan antara kurator dengan debitur. Dalam gugatannya, penggugat mendasarkan gugatan actio pauliana pada peristiwa tindakan debitur (PT HEI) yang mengalihkan/menjual seluruh asetnya (boedel pailit) kepada tergugat II (PT KPEI) pada November 2014 dengan harga 
total senilai USD1.405.358,13 dan aset berupa lima unit mobil senilai USD901,68. Kemudian tanggal 17 April 2015, tergugat I mentransfer dana sebesar USD562.452 kepada tergugat VII (KNM Pty Ltd), yang dilakukan dan ditandatangani oleh Finance Manager dan General Manager.

Penggugat mendalilkan, bahwa penjualan aset dilakukan para tergugat dengan iktikad buruk untuk menghindar dari kewajiban membayar dan melunasi seluruh utang-utangnya. Karena berdasarkan Putusan Homologasi Perdamaian antara tergugat I dengan para krediturnya, tanggal 8 Juli 2014, tergugat I dinyatakan pailit karena tidak membayar lunas utang kepada para krediturnya, yaitu FI Ltd; PT ESS; PT TAF; PT QS; dan PT MKB.

Perbuatan mengalihkan dengan cara menjual aset (boedel pailit) kepada tergugat II, dan mentransfer dana hasil penjualan kepada tergugat VII dalam kurun waktu satu tahun sebelum pernyataan pailit, dinilai dapat menimbulkan kerugian bagi para krediturnya. Meskipun terhadap dalil tersebut para tergugat mengajukan jawaban yang pada pokoknya membantah, dengan alasan bahwa penjualan aset yang dilakukan dan transfer dana dari tergugat I kepada tergugat VII, bertujuan supaya tergugat I tetap dapat beroperasi dan memenuhi kewajiban hutangnya kepada para krediturnya. Namun justru pengakuan para tergugat atau setidak-tidaknya tidak disangkal oleh para tergugat dan turut tergugat, dinilai hakim sebagai suatu peristiwa yang menurut hukum sudah terbukti.

Penilaian hakim tersebut sangat tepat karena dilakukan secara a contrario, bahwa pengakuan tergugat atas terjadinya peristiwa jual beli senilai USD1.405.358,13 dan transfer dana sebesar USD562.452 dari tergugat I kepada tergugat VII, yang disebut bertujuan agar tergugat I tetap dapat beroperasi dan memenuhi kewajiban hutangnya kepada para krediturnya, dinilai hakim sebagai peristiwa yang sengaja dilakukan tergugat untuk menghindar dari kewajiban membayar kepada para kreditur. Sehingga unsur mengetahui atau patut mengetahui bahwa akibat peristiwa tersebut dapat merugikan kreditur.

Terhadap alat bukti pengakuan mempunyai kekuatan alat bukti yang sempurna, sehingga hakim mau tidak mau harus menerima bahwa pengakuan tersebut sebagai suatu peristiwa yang benar-benar terjadi. Penilaian hakim terhadap adanya pengakuan telah terjadi penjualan aset yang dilakukan dan transfer dana dari tergugat I kepada tergugat VII, menjadi dasar hakim untuk menyatakan telah terbukti unsur mengetahui atau patut mengetahui. Penjualan aset dan transfer dana oleh tergugat I kepada tergugat VII, merupakan iktikad tidak baik dari tergugat yang dapat merugikan kreditur.

Perjanjian penjualan seluruh aset tergugat I (bukti P-6) hanya menyebutkan harga penjualan tanpa adanya pembayaran harga dari tergugat II kepada tergugat I, karena dinyatakan bahwa tergugat I mempunyai utang kepada perusahaan induk, dan hasil penjualan aset tergugat I tersebut langsung di-set off untuk membayar utang kepada Perusahaan Induk KNM Capital SDN BHD (tergugat VII). Dalam pertimbangannya, hakim menilai bahwa penjualan aset debitur kepada tergugat II dan pembayaran utang dilakukan kepada tergugat VII jelas sangat merugikan para kreditur tergugat I.

Hal ini didasarkan kepada Putusan Homologasi Perdamaian antara tergugat I dengan para krediturnya, bahwa tergugat VII tidak terverifikasi sebagai kreditur yang berhak 
menerima pembayaran dari tergugat I, di samping melanggar prinsip dalam ketentuan Pasal 1132 KUHPerdata, bahwa kewajiban hutang tersebut harus dilakukan berdasarkan prinsip pari passu pro rata parte, yakni bahwa harta kekayaan debitur menjadi jaminan bersama untuk para kreditur dan hasilnya harus dibagikan secara proporsional di antara mereka.

2) Perbuatan Itu Dilakukan Sebelum Putusan Pailit

Pembuktian terhadap pengalihan berupa penjualan aset tergugat I (boedel pailit) kepada tergugat II dan tindakan transfer dana tergugat I kepada tergugat VII dilakukan dalam jangka waktu satu tahun sebelum putusan pernyataan pailit diucapkan, terhadap tergugat I didasarkan pada bukti P-1 (Putusan Nomor 03/PDT. SUS/PEMBATALAN/2015/PN.NIAGA jo. Nomor 07/PKPU/2014/PN.NIAGA.MDN tanggal 9 Juli 2015), bukti P-4 (Penetapan Hakim Pengawas Nomor 02/HP/03/PDT.SUS/ PEMBATALAN/2015/PN.NIAGA jo. Nomor 07/PKPU/2014/ PN.NIAGA.MDN tanggal 30 Juli 2015) dan bukti P-5 (Putusan Homologasi Perdamaian Nomor 07/PKPU/2014/PN.NIAGA. MDN, tanggal 8 Juli 2014).

Berdasarkan alat bukti tersebut, hakim menilai penggugat dapat membuktikan bahwa benar PT HEI telah dinyatakan pailit, dan putusan tersebut telah diumumkan pada media dan Berita Negara. Melalui bukti P-1, penggugat diangkat sebagai kurator atas PT HEI (tergugat I), sehingga segala tindakan hukum yang berkenaan dengan pengurusan dan pemberesan harta pailit tergugat I harus diwakili oleh penggugat sebagai kurator.

Berdasarkan perjanjian jual beli aset tergugat I (bukti P-7) berupa lima unit mobil, tanggal 3 Desember 2014, bersesuaian dengan bukti P-6a dan bukti P-6b, dan dihubungkan dengan keterangan saksi NMW di bawah sumpah, yang pada pokoknya menerangkan bahwa saksi tidak mempunyai kewenangan mentransfer aset. Namun saksi mengetahui telah terjadi penjualan aset PT HEI kepada PT KPEI, karena perintah dan instruksi dari CFS (direktur tergugat I) dan LSE (komisaris tergugat I), saksi menandatangani purchase order yang diterbitkan oleh PT KPEI untuk melakukan pembelian terhadap aset PT HEI, dan saksi lakukan atas perintah dari CFS dan LSE.

Berdasarkan surat kuasa yang diberikan oleh direktur tergugat I kepada saksi, bahwa aset tergugat I yang dialihkan kepada tergugat II adalah berupa aset operasional, plant and equipment, motor vehicle, furniture, fitting, dan computer, dan lain sebagainya, tindakan tersebut terjadi bulan November 2014. Saksi mengetahui kalau nilai aset tersebut sebesar lebih kurang 1,4 juta Dolar Amerika.

Berdasarkan alat bukti surat (bukti P-7) dihubungkan dengan jawaban para tergugat yang pada pokoknya menyatakan, bahwa alasan penjualan aset dan transfer dana (bukti P-9a) supaya tergugat I tetap dapat beroperasi dan memenuhi kewajiban hutangnya kepada para kreditur, dinilai hakim sebagai fakta bahwa benar telah terjadi perjanjian jual beli aset tergugat I berupa lima unit mobil, tanggal 3 Desember 2014 dan transfer dana (bukti P-9a) yang dilakukan oleh tergugat I kepada tergugat VII pada tanggal 17 April 2015 senilai USD562.452 bersesuaian dengan keterangan saksi NMW di bawah sumpah yang pada pokoknya menerangkan, bahwa aset PT HEI yang dialihkan kepada PT KPEI adalah berupa aset operasional, yaitu plant and equipment, motor vehicle, furniture, fitting, dan computer, terjadi bulan November 2014. 
Dari bukti P-6a, bukti-P-6b, bukti P-7, bukti P-9a, bukti P-9b, bukti P-13, bukti P-14, bukti P-15, dan bukti P-16 dapat disimpulkan fakta bahwa benar tergugat I mengalihkan aset berupa boedel pailit dengan cara menjual kepada tergugat II, sekitar bulan November 2014 sampai bulan Januari 2015. Berdasarkan bukti P-1, bukti P-4, bukti P-5, dan bukti tersebut di atas, terungkap fakta bahwa benar pada tanggal 9 Juli 2015, tergugat I dinyatakan pailit, namun pada bulan November 2014 atau sekitar sembilan bulan sebelum putusan pailit, tergugat I telah mengalihkan seluruh asetnya kepada tergugat II, dan pada bulan April 2015 tergugat I telah melakukan transfer dana kepada tergugat VII. Berdasarkan hal tersebut, hakim menilai bahwa terbukti tindakan penjualan aset debitur pailit dan transfer dana dilakukan masih dalam tenggang waktu satu tahun sebelum putusan pernyataan pailit diucapkan pada tanggal 9 Juli 2015.

\section{3) Perbuatan Itu Tidak Diwajibkan Oleh Perjanjian atau Undang-Undang}

Gugatan penggugat pada pokoknya mempersoalkan adanya perbuatan tergugat I (debitur pailit) yang melakukan jual beli atas aset pailit kepada tergugat II, diikuti dengan transfer dana milik tergugat I kepada tergugat VII, di mana dapat dibuktikan bahwa para tergugat merupakan badan hukum yang berada dalam satu grup. Dalam jawabannya para tergugat mendalilkan bahwa alasan penjualan aset yang dilakukan oleh tergugat I kepada tergugat II, dan transfer dana dari tergugat I kepada tergugat VII, dilakukan agar tergugat I tetap dapat beroperasi dan memenuhi kewajiban hutangnya kepada para krediturnya. Hal ini memberikan keyakinan pada hakim bahwa oleh karena telah diakui atau setidak-tidaknya tidak disangkal oleh para tergugat dan turut tergugat, maka menurut hukum, peristiwa yang didalilkan oleh penggugat harus dianggap terbukti.

Sesuai dengan ketentuan Pasal 41 ayat (1) dan Pasal 42 Undang-Undang Nomor 37 Tahun 2004, kreditur dapat memintakan pembatalan kepada pengadilan segala perbuatan hukum debitur yang telah dinyatakan pailit yang merugikan kepentingan kreditur, yang dilakukan dalam jangka waktu satu tahun sebelum putusan pernyataan pailit diucapkan, sedangkan perbuatan tersebut tidak wajib dilakukan debitur. Jelas, bahwa perbuatan debitur yang dapat dimintakan untuk pembatalan kepada pengadilan adalah perbuatan hukum yang tidak diwajibkan, baik oleh perjanjian maupun oleh undang-undang.

Undang-Undang Nomor 37 Tahun 2004 tidak menjelaskan lebih lanjut pengertian dari perbuatan hukum debitur yang diwajibkan berdasarkan perjanjian maupun oleh undangundang, yang dikecualikan dari perbuatan debitur yang tidak dapat dimintakan pembatalan, selain hanya menyebutkan dalam Penjelasan Pasal 41 ayat (3), perbuatan yang wajib dilakukan karena undang-undang adalah pembayaran pajak, dan Penjelasan Pasal 39 ayat (2) menentukan bahwa pembayaran upah yang merupakan hak pekerja yang diterima dalam bentuk uang termasuk tunjangan bagi pekerja dan keluarga, merupakan kewajiban menurut suatu perjanjian atau peraturan perundang-undangan.

Sebagaimana diketahui bahwa hak kreditur dalam asas actio pauliana ini berkaitan dengan ketentuan Pasal 1131 KUHPerdata, yang menentukan bahwa semua harta kekayaan debitur menjadi jaminan atas hutang pada para krediturnya. Selanjutnya menurut Pasal 1132 KUHPerdata, semua harta kekayaan debitur 
menjadi jaminan bersama-sama bagi krediturnya, dan kewajiban membayar dilakukan menurut prinsip kesamaan dan keseimbangan, kecuali ada alasan yang sah untuk didahulukan. Piutang yang didahulukan pembayarannya dapat terjadi karena perjanjian maupun karena undang-undang.

Menurut Pasal 1133 KUHPerdata, hakhak yang didahulukan terbit dari perjanjian gadai dan hipotek, serta hak istimewa yang ditentukan dalam Pasal 1139 KUHPerdata. Jika dilihat dari tujuan perbuatan tergugat I (debitur pailit) yang melakukan jual beli atas aset pailit kepada tergugat II, diikuti dengan transfer dana milik tergugat I kepada tergugat VII, bukanlah merupakan perbuatan yang diwajibkan untuk dilakukan oleh debitur pailit. Bahkan berdasarkan bukti P-5 (Putusan Homologasi Perdamaian) tergugat I dengan para krediturnya dalam Putusan Nomor 07/PKPU/2014/PN.NIAGA.MDN), serta keterangan saksi NMW di persidangan terbukti PT KPEI (tergugat II), dan KNM Pty Ltd (tergugat VII) bukanlah merupakan bagian dari kreditur tergugat I yang sudah diverifikasi. Sehingga menurut majelis hakim penggugat dapat membuktikan dalilnya, bahwa jual beli yang dilakukan antara tergugat I dengan tergugat II dan transfer dana kepada tergugat VII, berakibat aset tergugat I menjadi tidak tersisa, yang akibatnya menimbulkan kerugian bagi krediturnya.

Telah terbuktinya perbuatan tergugat I (debitur pailit) yang membawa kerugian pada para krediturnya, dan perbuatan itu dilakukan dalam kurun waktu satu tahun sebelum putusan pailit diucapkan, serta perbuatan itu tidak diwajibkan oleh perjanjian atau undang-undang, maka harus dapat dibuktikan apakah perbuatan tersebut diketahui atau patut diketahui bahwa perbuatan hukum debitur dapat merugikan krediturnya. Sebagaimana disebutkan dalam Pasal 41 ayat (2), pembatalan hanya dapat dilakukan apabila dapat dibuktikan bahwa pada saat perbuatan hukum dilakukan, debitur dan pihak dengan siapa perbuatan hukum tersebut dilakukan, mengetahui atau sepatutnya mengetahui bahwa perbuatan hukum tersebut akan mengakibatkan kerugian bagi kreditur.

Pasal 42 huruf f Undang-Undang Nomor 37 Tahun 2004 menentukan bahwa apabila perbuatan hukum yang merugikan kreditur dilakukan dalam jangka waktu satu tahun sebelum putusan pernyataan pailit diucapkan, sedangkan perbuatan tersebut tidak wajib dilakukan, maka debitur dan pihak dengan siapa perbuatan tersebut dilakukan dianggap mengetahui atau sepatutnya mengetahui bahwa perbuatan tersebut akan mengakibatkan kerugian bagi kreditur.

Debitur atau pihak dengan siapa perbuatan tersebut dilakukan adalah anggota direksi atau pengurus atau apabila pihak tersebut, baik sendirisendiri maupun bersama-sama, ikut serta secara langsung atau tidak langsung dalam kepemilikan badan hukum tersebut lebih dari 50\% dari modal disetor atau dalam pengendalian badan hukum atau dilakukan oleh debitur yang merupakan badan hukum, dengan atau untuk kepentingan anggota direksi atau pengurus dari debitur yang ikut serta secara langsung atau tidak langsung dalam kepemilikan pada debitur lebih dari 50\% dari modal disetor atau dalam pengendalian badan hukum tersebut atau dilakukan oleh debitur yang merupakan badan hukum dengan atau untuk kepentingan badan hukum lainnya, apabila anggota direksi atau pengurus pada kedua badan usaha tersebut adalah orang yang sama, direksi atau pengurus debitur yang juga merupakan anggota direksi atau pengurus pada badan hukum lainnya. 
Dalam Penjelasan Pasal 42 huruf $f$ Undang-Undang Nomor 37 Tahun 2004 tersebut dijelaskan bahwa dimaksud dengan "anggota direksi" adalah anggota badan pengawas, atau orang yang ikut serta dalam kepemilikan, termasuk setiap orang yang pernah menduduki posisi tersebut dalam jangka waktu kurang dari satu tahun sebelum dilakukannya perbuatan tersebut, dan kepemilikan adalah kepemilikan modal atau modal saham.

Pertimbangan hakim menilai bahwa bukti P-2a dan P-2b, berupa fotocopy Struktur Perusahaan KNM Grup Berhad yang berpusat di Malaysia, membuktikan bahwa para tergugat dan para turut tergugat merupakan bagian dari Perusahaan KNM (tergugat VII), dan bukti P-6a, P-6b, P-12a, P-12b, P-15a, P-15b, P-16a, P-16b, membuktikan bahwa transaksi penjualan aset tergugat I kepada tergugat II masing-masing ditandatangani oleh orang yang sama, yakni CFS Direktur PT HEI (tergugat III) dan sebagai Direktur PT KPEI (tergugat V), LSE sebagai Komisaris PT HEI (tergugat IV) dan juga sebagai Komisaris PT KPEI (tergugat VI). Bukti P-23a dan $\mathrm{b}$ berupa Laporan Aset Tetap tergugat I per tanggal 30 November 2014, menunjukkan bahwa dalam Tanda Daftar Perusahaan dan Surat Keterangan Domisili PT HEI dan PT KPEI adalah atas nama orang yang sama, yakni CFS sebagai direktur.

Alat bukti surat tersebut juga bersesuaian dengan keterangan saksi NMW di bawah sumpah, yang pada pokoknya menerangkan bahwa Perusahaan KPE adalah grup dari Australia yang terdiri dari Exchanger Indonesia. KPE adalah anak dari perusahaan dan memiliki mesin-mesin serta alat-alat produksi lainnya serta peralatan kantor yang sama dan nomor telepon yang sama, dan saksi menerangkan bahwa ia diangkat dan bekerja sekaligus di dua perusahaan yang sama, yakni PT HEI dan PT KPEI sebagai General Manager. Saat terjadinya pengalihan aset PT HEI kepada PT KPEI dilakukan oleh kedudukan kedua orang tersebut di kedua perusahaan yang sama. Selanjutnya saksi NMW menerangkan uang hasil penjualan aset tergugat I tidak masuk ke dalam kas perusahaan PT HEI, melainkan ditransfer ke KNM CAPITAL SDN BHD (turut tergugat II). Sehingga disimpulkan bahwa benar jual beli aset dilakukan antara tergugat I dengan tergugat II, dan transfer dana dari tergugat I ke tergugat VII yang merupakan badan hukum yang berada dalam satu grup.

Gugatan penggugat mengenai adanya jual beli dan transfer dana yang dilakukan oleh badan hukum yang merupakan satu grup, jika didasarkan pada Pasal 42 huruf (f) Undang-Undang Nomor 37 Tahun 2004, yang menentukan bahwa apabila perbuatan hukum yang merugikan kreditur dilakukan dalam jangka waktu satu tahun sebelum putusan pernyataan pailit diucapkan, sedangkan perbuatan tersebut tidak wajib dilakukan debitur, kecuali dapat dibuktikan sebaliknya, maka terbukti bahwa debitur dan pihak dengan perbuatan tersebut dilakukan dianggap mengetahui atau sepatutnya mengetahui bahwa perbuatan tersebut akan mengakibatkan kerugian bagi kreditur.

Dengan demikian, terbuktinya para tergugat dan turut tergugat merupakan satu grup, dan perbuatan hukum tergugat I yang menjual aset kepada tergugat II dan transfer dana kepada tergugat VII dilakukan dalam jangka waktu satu tahun sebelum putusan pernyataan pailit diucapkan, maka hakim menilai bahwa penggugat dapat membuktikan bahwa pada saat perbuatan hukum dilakukan, debitur (tergugat I) dan pihak dengan siapa perbuatan hukum tersebut 
dilakukan (tergugat II dan tergugat VII) sudah mengetahui atau sepatutnya mengetahui bahwa perbuatan hukum tersebut akan mengakibatkan kerugian bagi kreditur. Oleh karena itu, hakim menilai bahwa tuntutan pembatalan tersebut harus dikabulkan.

\section{B. Pertimbangan Hukum}

Salah satu amar Putusan Nomor 07/PDT. SUS-ACTIO PAULIANA/2015/PN.NIAGA. MDN menyatakan bahwa perbuatan hukum tergugat I dalam jual beli aset kepada tergugat II, dan pengalihan dana oleh tergugat I kepada tergugat VII merupakan perbuatan melawan hukum. Putusan hakim tersebut tentu saja sudah didasarkan pada pertimbangan-pertimbangan berdasarkan alat-alat bukti yang diajukan oleh para pihak.

Hal ini sesuai dengan asas umum beracara di pengadilan, yaitu putusan harus disertai alasan sebagai dasar untuk mengadili yang terkandung dalam Pasal 50 ayat (1) Undang-Undang Kekuasaan Kehakiman jo. Pasal 184 ayat (1) HIR/195 ayat (1) Rbg. Alasan atau pertimbangan menjadi dasar pertanggungjawaban hakim pada putusannya (Mertokusumo, 2013: 15). Untuk menentukan adanya perbuatan melawan hukum berdasarkan Pasal 1365 KUHPerdata tersebut, diharuskan penggugat membuktikan semua unsur-unsur perbuatan melawan hukum, yaitu adanya perbuatan melanggar hukum, adanya kesalahan, adanya kerugian, dan antara kerugian dan kesalahan mempunyai hubungan sebab akibat.

Pengertian keempat unsur tersebut tidak dijelaskan selanjutnya, tetapi diserahkan kepada hakim untuk selalu menyesuaikan kaidah yang terdapat di dalamnya, dengan perkembangan kepentingan dalam masyarakat. Oleh karena norma hukum yang terdapat di dalamnya (blanket norm) selalu berkembang seiring dengan perkembangan masyarakat, maka hakim dipaksa untuk selalu melakukan penemuan hukum melalui putusannya.

Pertimbangan hakim menyatakan bahwa untuk mengkualifikasi perbuatan hukum debitur sebagai perbuatan melawan hukum, maka harus dibuktikan apakah penjualan aset tergugat I (boedel pailit) kepada tergugat II, dan transfer dana dari tergugat I kepada tergugat VII dilakukan oleh badan hukum yang satu grup, sehingga mengakibatkan kerugian bagi kreditur tergugat I. Pertimbangan hakim tersebut sesuai dengan ketentuan Pasal 42 Huruf (f ) Undang-Undang Nomor 37 Tahun 2004, bahwa perbuatan hukum yang dilakukan oleh debitur yang merupakan badan hukum dengan atau terhadap badan hukum lain dalam satu grup di mana debitur adalah anggotanya, merupakan perbuatan melawan hukum karena mengakibatkan kerugian pada kreditur.

Untuk lebih mendalami dasar penilaian hakim dalam mengkualifikasi perbuatan hukum debitur sebagai perbuatan melawan hukum, perlu diuraikan dua macam bentuk perbuatan hukum yang dilakukan oleh debitur, yaitu perbuatan jual beli antara tergugat I dengan tergugat II dan perbuatan mentransfer dana hasil penjualan aset kepada tergugat VII. Pertimbangan hakim yang didasarkan pada pengertian perbuatan melanggar undang-undang, selain yang sudah diatur dalam Pasal 42 Huruf (f ) Undang-Undang Nomor 37 Tahun 2004, maka perbuatan hukum debitur juga bertentangan dengan ketentuan hukum sebagaimana diuraikan selanjutnya. 
1)

Perjanjian Penjualan Aset

Penilaian hakim memberikan kualifikasi terhadap perbuatan penjualan aset tergugat I (boedel pailit) kepada tergugat II, dan transfer dana dari tergugat I kepada tergugat VII sebagai perbuatan melawan hukum, karena jual beli aset tergugat dilakukan oleh orang (pihak) yang sama. Hal ini bertentangan dengan Pasal 1457 KUHPerdata yang menentukan jual beli adalah suatu persetujuan yang mengikat pihak penjual berjanji menyerahkan sesuatu barang/benda, dan pihak lain yang bertindak sebagai pembeli mengikat diri berjanji untuk membayar harga. Jika disimak pengertian perjanjian jual beli tersebut sebagai suatu perikatan, maka perjanjian jual beli harus terjadi antara dua pihak yang berada dalam posisi yang berbeda, di mana pihak yang satu adalah pihak yang berhak (kreditur) atas suatu prestasi, dan pihak lainnya merupakan pihak yang wajib melaksanakan prestasi (debitur).

Berdasarkan Laporan Aset Tetap tergugat I per tanggal 30 November 2014, menunjukkan bahwa dalam Tanda Daftar Perusahaan dan Surat Keterangan Domisili PT HEI dan PT KPEI adalah atas nama orang yang sama, yakni CFS sebagai direktur. Di samping itu, majelis hakim menilai bantahan para tergugat yang pada dasarnya menyatakan bahwa penjualan aset tergugat I kepada tergugat II, dan transfer dana tergugat I sebesar USD562.452 kepada tergugat VII (KNM Pty Ltd), dilakukan dan ditandatangani oleh Finance Manager dan General Manager sesuai dengan kewenangannya, guna memenuhi kewajiban pembayaran cicilan hutang tergugat I kepada para kreditur agar dapat tetap beroperasi, tidak terbukti oleh karena berdasarkan aturan Batas Kewenangan Keuangan Perusahaan (Financial Limited Authority) yang berlaku di grup para tergugat.
Berlaku juga untuk tergugat I, bahwa untuk transaksi di atas USD100.000 adalah kewenangan CEO perusahaan ke atas dan telah dilengkapi dengan dokumen pendukungnya, berupa purchase order, invoice, delivery order, MRR (material resitting report), dan dokumendokumen pendukung lainnya. Namun transfer yang dilakukan oleh tergugat I kepada tergugat VII (bukti P-9) dilakukan tanpa dokumen pendukung dan dilakukan oleh orang yang jabatannya di perusahaan berada di bawah CEO. Hal ini membuktikan bahwa transfer dana tersebut tanpa tujuan yang jelas dan melanggar aturan dan ketentuan dalam perusahaan.

\section{2) Perbuatan Set Off}

Putusan hakim juga menilai bahwa mengalihkan melalui penjualan aset debitur kepada tergugat II dengan cara set off, yaitu pembayaran tidak dilakukan kepada tergugat I, namun hasil penjualan tersebut langsung di-set off kepada perusahaan induk (tergugat VII), yang mengakibatkan tergugat I tidak dapat lagi melunasi utang kepada krediturnya, karena pembayaran hasil penjualan seluruh aset tergugat I tidak dilakukan kepada tergugat I. Dalam bantahannya, pihak tergugat mengatakan bahwa tindakan pembayaran kepada tergugat VII dengan cara set off sesuai dengan kompensasi atau perjumpaan hutang yang merupakan salah satu syarat untuk mengakhiri perikatan.

\section{Menurut Pasal 1425 KUHPerdata,} perjumpaan hutang merupakan perjumpaan dua hutang piutang antara orang yang sama secara bertimbal balik dengan cara saling diperhitungkan, sehingga salah satu atau keduanya menjadi dihapus. Kompensasi atau perjumpaan hutang sehubungan dengan dihapusnya perikatan 
diartikan sebagai perjumpaan dua utang piutang antara orang yang sama, di mana para pihak berkedudukan sebagai kreditur dan debitur satu sama lain.

Berdasarkan Pasal 1426 KUHPerdata, perjumpaan terjadi demi hukum bahkan dengan tidak setahunya orang-orang yang berutang. Ketentuan tersebut menurut pertimbangan hakim, yang didasarkan pada pendapat Subekti, bahwa perjumpaan hutang atau kompensasi itu tidak terjadi secara otomatis, tetapi harus diajukan atau diminta oleh pihak yang berkepentingan. Atas dasar tersebut, hakim menilai bahwa pengalihan aset dan transfer dana hasil pembayaran kepada tergugat VII dengan set off tidak sesuai dengan ketentuan Pasal 1425, 1426, 1427 KUHPerdata, sehingga pengalihan aset tersebut diartikan sebagai suatu perbuatan jual beli bukan merupakan set off.

Berdasarkan uraian-uraian tersebut, diketahui bahwa pertimbangan hukum yang diberikan oleh hakim untuk menyatakan perbuatan para tergugat merupakan perbuatan melawan hukum didasarkan pada dua macam perbuatan hukum tergugat I (debitur pailit), yaitu perbuatan tergugat I dengan tergugat II yang melakukan jual beli aset tergugat I. Sedangkan berdasarkan bukti P-23a dan P-23b, berupa Laporan Aset Tetap tergugat I per tanggal 30 November 2014 dalam Tanda Daftar Perusahaan dan Surat Keterangan Domisili, bersesuaian dengan keterangan saksi NMW di bawah sumpah yang pada pokoknya menerangkan, bahwa Perusahaan KPE adalah grup dari Australia, antara tergugat I dan tergugat II adalah atas nama orang yang sama, yakni CFS sebagai direktur dan saksi, diangkat dan bekerja sekaligus di dua perusahaan yang sama, yakni PT HEI (tergugat I) dan PT KPEI (tergugat II) sebagai General Manager.
Menurut Pasal 1457 KUHPerdata, jual beli merupakan persetujuan antara dua pihak yang berbeda, di mana pihak penjual berjanji menyerahkan sesuatu barang/benda, dan pihak pembeli wajib membayar harga. Kemudian perbuatan tergugat I yang melakukan transfer dana hasil pembayaran kepada tergugat VII dengan set off tidak sesuai dengan ketentuan Pasal 1425, 1426, 1427 KUHPerdata, karena menurut hakim perjumpaan hutang atau kompensasi itu tidak terjadi secara otomatis, tetapi harus diajukan atau diminta oleh pihak yang berkepentingan. Sebagaimana juga disebutkan oleh Mariam Darus dalam bukunya Sidabalok (2017: 229), kompensasi yang terjadi secara otomatis dapat mengakibatkan terjadinya ketegangan di antara para pihak. Oleh karenanya dalih tergugat untuk mengurangi hutang tergugat I kepada krediturnya, seharusnya diajukan terlebih dahulu sebagai kreditur yang berhak mendapatkan pembayaran, kecuali kreditur yang mempunyai hak preferensi berdasarkan undang-undang ataupun perjanjian. Namun bukti P-5 berupa Putusan Homologasi Perdamaian ]tergugat I dengan para krediturnya serta keterangan saksi NMW di persidangan, terbukti bahwa tergugat VII bukanlah merupakan bagian dari kreditur tergugat I yang berhak memperoleh pembayaran/pelunasan hutang dari hasil penjualan aset tergugat I.

\section{KESIMPULAN}

Sesudah dilakukan analisis terhadap permasalahan yang diajukan, maka dapat ditarik kesimpulan, bahwa:

1. Penilaian hakim terhadap pembuktian adanya unsur mengetahui atau sepatutnya mengetahui sebagai dasar tuntutan actio pauliana, didasarkan pada pengakuan 
tergugat bahwa terjadi penjualan aset dan transfer dana dari tergugat I kepada tergugat VII, untuk tujuan agar tergugat I tetap dapat beroperasi dan memenuhi kewajiban hutangnya kepada para krediturnya. Namun melalui penafsiran a contrario, hakim menilai bahwa perbuatan tersebut diketahui oleh debitur dan dapat merugikan krediturnya.

2. Pertimbangan hakim untuk menyatakan bahwa perbuatan para tergugat merupakan perbuatan melawan hukum didasarkan pada perbuatan jual beli tersebut dilakukan oleh orang yang sama, sehingga bertentangan dengan Pasal 1457 KUHPerdata. Tidak dilakukan orang yang berwenang sebagaimana disebutkan dalam Peraturan Batas Kewenangan Keuangan Perusahaan (Financial Limited Authority) yang berlaku di grup perusahaan, serta pembayaran oleh tergugat I kepada tergugat VII dengan cara set off tidak sesuai dengan Pasal 1425, 1426, 1427 KUHPerdata.

\section{DAFTAR ACUAN}

Butarbutar, E.N. (2001). Relevansi pengadilan negeri/niaga dalam menyelesaikan perkara utang piutang. Thesis. Yogyakarta: Program Pascasarjana Fakultas Hukum Universitas Gadjah Mada.

(2012). Hukum harta kekayaan, menurut sistematika KUHPerdata \& perkembangannya. Cetakan Kesatu. Bandung: PT Refika.

(2016). Hukum pembuktian, analisis terhadap kemandirian hakim sebagai penegak hukum dalam proses pembuktian. Edisi Pertama. Bandung: CV Nuansa Aulia. (2018). Metode peneltian hukum, langkah-langkah untuk menemukan kebenaran dalam ilmu hukum. Cetakan Kesatu. Bandung: PT Refika.

Djojodirdjo, M.A.M. (1979). Perbuatan melawan hukum. Jakarta: Pradnya Paramita.

Fajar, M., \& Achmad, Y. (2015). Dualisme penelitian hukum normatif \& empiris. Yogyakarta: Pustaka Pelajar.

Marzuki, P.M. (2014). Penelitian hukum. Jakarta: Prenamedia Group.

Mertokusumo, S. (2013). Hukum acara perdata Indonesia. Edisi Revisi. Yogyakarta: Cahaya Atma Pustaka.

Miru. A. (2017). Hukum kontrak \& perancangan kontrak. Cetakan Ketujuh. Jakarta: Rajawali Perss.

Paton, G.W. (1975). A text book of jurisprudence. Oxford: Clarendon Press.

Samosir, D. (2011). Hukum acara perdata, tahaptahap penyelesaian perkara perdata. Edisi Pertama. Bandung: CV Nuansa Aulia.

Satrio, J. (1993). Hukum perikatan, perikatan pada umumnya. Bandung: Citra Aditya Bakti.

Siahaan, R.H. (2017). Hukum perikatan Indonesia, teori \& perkembangannya. Cetakan I. Malang: Inteligensia Media.

Sidabalok, J. (2012). Hukum perusahaan, analisis terhadap pengaturan peran perusahaan dalam pembangunan ekonomi nasional di Indonesia. Bandung: Nuansa Aulia. . (2017). Hukum perdata menurut KUHPerdata \& perkembangannya di dalam 
perundang-undangan Indonesia. Medan: USU Press.

Soejono \& Abdurahman, H. (2003). Metode penelitian hukum. Jakarta: Rineka Cipta.

Soekanto, S. (2012). Pengantar penelitian hukum. Jakarta: UI Press.

Subekti, R. (2007). Hukum pembuktian. Cetakan Keenambelas. Jakarta: Pradnya Paramita. 